\title{
Phytoprotection
}

\section{Plant parasitic nematodes and their management in the Maritime provinces of Canada}

\section{J. Kimpinski et L.S. Thompson}

Volume 71, numéro 2, 1990

URI : https://id.erudit.org/iderudit/705982ar

DOI : https://doi.org/10.7202/705982ar

Aller au sommaire du numéro

Éditeur(s)

Société de protection des plantes du Québec (SPPQ)l

ISSN

0031-9511 (imprimé)

1710-1603 (numérique)

Découvrir la revue

Citer cet article

Kimpinski, J. \& Thompson, L. (1990). Plant parasitic nematodes and their management in the Maritime provinces of Canada. Phytoprotection, 71(2), 45-54. https://doi.org/10.7202/705982ar
Résumé de l'article

Cet article présente une revue des nematodes phytoparasites qui causent des problèmes au Nouveau-Brunswick, en Nouvelle-Ecosse et à l'île-du Prince-Édouard, ainsi que les approches de lutte utilisées. Le nématode des lésions des racines (Pratylenchus penetrans) est la seule espèce de nématode de la région qui provoque régulièrement des baisses de rendement. Le nématode des nodosités des racines (Meloidogyne hapla) cause occasionnellement des dommages aux carottes (Daucus carota) mais les niveaux de population de ce nématode sont généralement très faibles. Le nématode du kyste du trèfle (Heterodera trifolii) est répandu mais il n'a pas causé de dommages aux récoltes de la région. Les techniques de production utilisées afin de réduire l'impact des nematodes phytoparasites dans les Maritimes, à savoir la rotation des cultures, les traitements nématicides, le renforcement des règlements de quarantaine et les pratiques de labourage, sont discutées. Un service-conseil sur les nematodes est également considéré. 


\title{
Plant parasitic nematodes and their management in the Maritime provinces of Canada
}

\author{
J. Kimpinski and L.S. Thompson \\ Research Station, Agriculture Canada, P.O. Box 1210, \\ Charlottetown, Prince Edward Island, Canada C1A 7M8. Contribution No. 710.
}

(Received 1989-07-24; accepted 1990-02-15)

\begin{abstract}
This paper presents a review of the plant parasitic nematodes that are of concern in New Brunswick, Nova Scotia, and Prince Edward Island, and the approaches used to manage them. The root lesion nematode (Pratylenchus penetrans) is the only nematode species in the region that regularly reduces crop yields. The northern root-knot nematode (Meloidogyne hapla) occasionally causes damage to carrots (Daucus carota), but population levels of this nematode species usually are very low. The clover cyst nematode (Heterodera trifolii) is widespread, but has not caused any damage to crops in the region. Management procedures used to reduce the impact of plant parasitic nematodes in the Maritime provinces, e.g. crop rotations, nematicide treatments, enforcement of quarantine regulations, and tillage practices are discussed. A nematode advisory service is also considered.
\end{abstract}

Kimpinski, J., and L.S. Thompson. 1990. Plant parasitic nematodes and their management in the Maritime provinces of Canada. PHYTOPROTECTION 71: 45-54.

Cet article présente une revue des nématodes phytoparasites qui causent des problèmes au Nouveau-Brunswick, en Nouvelle-Écosse et à l'Île-du-Prince-Édouard, ainsi que les approches de lutte utilisées. Le nématode des lésions des racines (Pratylenchus penetrans) est la seule espèce de nématode de la région qui provoque régulièrement des baisses de rendement. Le nématode des nodosités des racines (Meloidogyne hapla) cause occasionnellement des dommages aux carottes (Daucus carota) mais les niveaux de population de ce nématode sont généralement très faibles. Le nématode du kyste du trèfle (Heterodera trifolii) est répandu mais il n'a pas causé de dommages aux récoltes de la région. Les techniques de production utilisées afin de réduire l'impact des nématodes phytoparasites dans les Maritimes, à savoir la rotation des cultures, les traitements nématicides, le renforcement des règlements de quarantaine et les pratiques de labourage, sont discutées. Un service-conseil sur les nématodes est également considéré.

\section{Introduction}

The first report in a scientific journal of a nematode problem in agricultural crops in the Maritime provinces of Canada concerned an infestation in a potato (Solanum tuberosum L.) field on Prince Edward Island by the potato rot nematode, Ditylenchus destructor Thorne (Baker 1946). As a consequence, two small regions, totalling several hundred hectares, and one field at a third location, were taken out of potato production. In a survey by Waseem and Craig (1962), plant parasitic nematodes were collected from 49 strawberry (Fragaria virginiana Duch.) fields in Nova Scotia. Root lesion nematodes (Pratylenchus spp.) were the most widespread and

$\overline{0031-9511 / 90} \$ 1.00+.10$ were recovered from $90 \%$ of the sites. Further work in Nova Scotia with alkyl halide fumigants, such as D-D (mixture of 1,3-dichloropropane, 1,2-dichloropropane and related hydrocarbons), and Nemagon (1,2-dibromo-3-chloropropane) showed that strawberry yields usually were increased (Morgan 1964) when populations of the root lesion nematode, $P$. penetrans (Cobb) Filipjev and Schuurmans-Stekhoven were suppressed.

Thompson and Willis (1967) found large populations of root lesion nematodes in red clover (Trifolium pratense L.) on Prince Edward Island and inferred that nematode parasites might be an important factor in the root decay problem of this crop. Subsequent investigations indicated that large numbers of $P$. penetrans reduced foliage yields of alfalfa (Medicago sativa L.), birdsfoot trefoil (Lotus corniculatus L.), red clover, 
and white clover (Trifolium repens L.) under field conditions and in the greenhouse (Thompson and Willis 1970; Willis and Thompson 1969a, 1969b). Surveys conducted in Nova Scotia, New Brunswick, and Prince Edward Island, recovered 29 species of plant parasitic nematodes (Willis and Thompson 1967; Willis et al. 1976). Pratylenchus spp. were common in alfalfa, alsike clover (Trifolium hybridum L.), birdsfoot trefoil, red clover, and white clover. Meloidogyne hapla Chitwood was the only species of root-knot nematode recovered from these surveys, and it was found in about $50 \%$ of the sites.

Surveys conducted on potato in the Maritime provinces, have indicated that Pratylenchus spp. are the dominant plant parasitic nematodes in roots and soil (Kimpinski 1979, 1987; Kimpinski and Smith 1988). Similarly, root lesion nematodes (primarily $P$. penetrans) are the dominant plant parasitic nematodes in tobacco ( $\mathrm{NiCO}$ tiana tabacum L.), barley (Hordeum vulgare L.), wheat (Triticum aestivum L.), strawberry, and several vegetable crops (Kimpinski 1975; Kimpinski et al. 1976, 1989).

Nematicide trials have revealed that root lesion nematodes were capable of causing yield losses of $25 \%$ or more in susceptible potato cultivars such as 'Superior' (Kimpinski 1986). Field trials also indicated that large populations of root lesion nematodes can reduce yields of tobacco and barley by about $15 \%$ (Arsenault et al. 1989; Kimpinski et al. 1987).

The two other species of plant parasitic nematodes that have caused some concern in the Maritime provinces are the northern root-knot nematode, M. hapla, and the clover cyst nematode, Heterodera trifolii Goffart. The northern root-knot nematode is found on forage legumes in the region (Willis et al. 1976), but populations are usually quite low and often difficult to detect in vegetable crops and potato (Kimpinski 1975, 1987; Kimpinski and Smith 1988). Outside of a few isolated occurrences in carrots (Daucus carota L.), root-knot nematodes have not caused any damage to crops in the region, but their potential as pathogens requires that they be monitored continually (Sasser and Carter 1985). Under greenhouse conditions, Willis $(1976,1981)$ found that alfalfa, birdsfoot trefoil, crown vetch (Coronilla varia L.), red clover, and sainfoin (Onobrychis viciifolia Scop.) were susceptible to damage from $M$. hapla. The clover cyst nematode is also widespread in forage legumes, but it has not caused any measurable damage in the region (Willis et al. 1971, 1976). Although potatces are not a host for $H$. trifolii, it may survive as a cyst in soil for extended time periods. A cyst is the body of a dead female and is a round saclike structure with a moisture-resistant wall. Each cyst may contain several hundred viable eggs that are protected from adverse conditions for many months or even years (Williams 1978). Although there is some concern that cysts of $H$. trifolii may be present in soil adhering to seed potato tubers, Kimpinski and Platt (1983) indicated that the probability of this occurring was very low.

In agriculture, the terms pest control and pest management are often used to convey the same meaning. For plant parasitic nematodes, Thomason and Caswell (1987) considered nematode control as a specific tactic that is utilized to reduce or eliminate nematode populations, while nematode management referred to the use of multiple control procedures to reduce the numbers of nematodes to levels that would not adversely affect host plants. Thomason and Caswell (1987) also stated that development of a management program for a particular nematode species should be done in a systematic way with specific objectives. If the species are limited in their distribution, the objective may be eradication or containment in a small geographic area, such as the potato cyst nematode (Globodera rostochiensis [Wollenweber] Behrens) in Newfoundland (Morris 1971).

Eradication appears to have been done successfully for the potato rot nematode $(D$. destructor) on Prince Edward Island, where removal of land from potato production has reduced the nematode population to nondetectable levels, and perhaps to zero (J. Kimpinski, unpublished data). However, if the nematode species are established and widespread, as is the case for root lesion, root-knot and clover cyst nematodes in the Maritime provinces of Canada, then eradi- 
cation is not practicable, and management procedures must be utilized. Management techniques are: crop rotations with non-host or poor host rotational crops in sequence with relatively tolerant main crop cultivars, application of nematicides, quarantine and sanitation, and cultural practices. A nematode advisory service must also complement management techniques.

\section{Crop rotations}

Crop rotations have been used successfully to reduce nematode populations in many commercial annual crops throughout the world, and those nematode species with a narrow host range are most effectively controlled by this method (Nusbaum and Ferris 1973). In many agricultural systems, crop rotations are the only economic means of control, largely because resistant crops are not available or crop values are too low to justify costly nematicide treatments. However, even with annual crops, the development of crop rotation programs is often constrained by specialized cropping practices in certain geographic areas, regional climate, and markets for main crops. For example, if one looks at the alternatives to growing cereals in Western Canada, the choice of an economically profitable crop rotation is limited.

The basic principles of crop sequences for management or control of nematode populations are: (a) to reduce pathogenic nematode populations to levels where they have no economic effect on the crop, (b) to attempt to preserve the beneficial organisms, and (c) to maintain soil conservation and fertility. Crop sequences are devised to regulate rather than eliminate nematode pest populations. Strategies are based on an understanding of population dynamics and life cycles of nematode pests and of economic values of crops in the rotation.

In the Maritime provinces, and particularly on Prince Edward Island, the approach has been to study the development of nematode populations in main crops and in rotational crops. The main crop is usually potato, but tobacco is still an important crop which is susceptible to nematode damage. The rotation crops are cereals such as wheat and barley, forage legumes such as red clover and alfalfa, grasses such as timothy (Phleum pratense L.) and annual ryegrass (Lolium multiflorum Lam.), and more recently, soybean (Glycine max [L.] Merr.). As mentioned above, initial surveys in forage legumes and grasses, and subsequent surveys in cereals, potato, tobacco, corn (Zea mays L.), lupine (Lupinus albus L.), soybean (Kimpinski 1984; Kimpinski and MacLeod 1988), and vegetables have shown that root lesion nematodes were predominant.

Pratylenchus penetrans is usually the most common root lesion nematode species, but a closely related species, Pratylenchus crenatus Loof, is also widespread. Pratylenchus crenatus is not considered a serious pathogen in agricultural crops in the Maritime provinces, but $P$. penetrans has reduced yields significantly in tobacco or potato on Prince Edward Island (Arsenault et al. 1989; Kimpinski 1982, 1986), in Ontario (Elliot et al. 1972; Olthof et al. 1985), and in the United States (Barker and Lucas 1984; Brodie 1984).

The development of root lesion nematodes has been monitored in various crops grown on the same site for three years (Kimpinski and Willis 1980; Kimpinski et al. 1984). The numbers of $P$. penetrans increased 25 and 50 fold to respective levels of 16500 nematodes per $\mathrm{g}$ of root and 55200 nematodes per $\mathrm{kg}$ of soil, at harvest after three consecutive years of corn. A red clover-timothy mixture and timothy alone were also excellent nematode hosts, and there were substantial increases in numbers of root lesion nematodes during the same period. Nematode populations also increased in wheat, but to a lesser degree than in red clover or timothy. Bromegrass (Bromus inermis Leyss.) and orchardgrass (Dactylis glomerata L.) were relatively poor hosts. The most interesting aspect of these studies was the very low numbers of root lesion nematodes recovered from annual ryegrass over the three-year period. These observations agreed with earlier studies under similar field conditions in upper New York state where annual ryegrass and bromegrass were relatively poor hosts for $P$. penetrans while soybean was a good host (MacDonald and Mai 1963). 
A subsequent survey of commercial fields on Prince Edward Island confirmed that populations of Pratylenchus spp. were at least five times as high in red clover fields as in annual ryegrass fields (Kimpinski et al. 1988). However, the population levels of root lesion nematodes in ryegrass in this survey were greater than in the earlier observations. This may have been due to large nematode populations in previous crops, but another aspect is the possible effect of ryegrass on the genetic make-up of root lesion nematode populations in specific locations. Nusbaum and Ferris (1973) stated that cropping systems can exert selection pressure to such an extent that resistance breaking pathotypes can emerge and reduce the effectiveness of the rotation.

The relatively low densities of root lesion nematodes usually found in annual ryegrass is one reason why this crop is now recommended as a rotational crop with potato on Prince Edward Island. Annual ryegrass is neither a host for the northern root-knot nematode, $M$. hapla, which can parasitize potato (Taylor and Sasser 1978), nor a host for the clover cyst nematode, $H$. trifolii, which does not attack potato, but is sometimes found in the soil adhering to tubers (Williams 1978). Several Latin American countries which import seed potatoes from New Brunswick and Prince Edward Island are concerned about the possible entry of these nematode species along with tubers. An added advantage of annual ryegrass is that the Italian and Westerwolds types thrive in the Maritime provinces and agronomic studies have suggested that they can be grown successfully for pasture and conserved forage (Kunelius 1980; Kunelius and Calder 1978). Large quantities of root mass are produced in the plow layer, particularly by Italian ryegrass, and soil organic matter and aggregate stability are increased. Therefore, if the control of root lesion, root-knot, and clover cyst nematodes is a primary objective in an integrated pest management program, the substitution of annual ryegrass for the more conventional red clovertimothy mixture in rotation with potato is a reasonable option for growers.

Nematode population levels have been monitored in lupine and soybean (Kimpinski 1984; Kimpinski and MacLeod 1988).
Under field conditions on Prince Edward Island, both host plants harbored moderate populations of northern root-knot nematodes, and soybean was also an excellent host for root lesion nematodes. Root-knot nematodes were scarce in soybean in a 1983 survey, but in 1987 population levels were much higher. Whether there was a real increase in numbers of root-knot nematodes over time, or the increase was due to differences between sites, cannot be stated with certainty.

As indicated, there is much evidence that $P$. penetrans and $M$. hapla can reduce yields of potato and tobacco at various locations in North America (Barker and Lucas 1984; Brodie 1984). More specifically, $P$. penetrans has reduced yields of potato and tobacco under field conditions on Prince Edward Island (Arsenault et al. 1989; Kimpinski 1986). To date, there is no information on the direct effects of different rotations or the previous crop on potato tuber yields in the Maritime provinces. However, it has been determined in experimental plots that 2000 to 3000 root lesion nematodes per $\mathrm{kg}$ of soil at planting will affect tuber yields significantly in a nematode-susceptible cultivar such as 'Superior' (Kimpinski and McRae 1988). Based on this indirect evidence, it has been possible to make recommendations as to which crop should precede a main crop such as potato. For example, at the present time, the recommendation to growers is to avoid soybean if the next crop is 'Superior' potato. If root lesion nematodes are a recurring problem in potato, or where root-knot or clover cyst nematodes may hinder the export of seed tubers to foreign markets, the substitution of annual ryegrass for timothy and red clover may be recommended.

Planting soybean prior to tobacco on Prince Edward Island was associated with higher densities of $P$. penetrans and lower tobacco yields than when rye was the preceding crop (Arsenault et al. 1989). These results suggested that tobacco growers on Prince Edward Island who do not fumigate for nematode control should avoid planting soybean in the year preceding tobacco. An alternative is to grow a crop prior to tobacco which does not harbor many root lesion nematodes, if soybean is in 
the rotation. This latter option currently is being studied under field conditions in the Maritime region of Canada.

In some cases, suppression of one nematode species with a certain crop may lead to larger populations of another species. For example, on Prince Edward Island, corn is not a suitable host for the northern root-knot nematode and will suppress populations of this species, but the numbers of root-lesion nematodes may become very large (Kimpinski et al. 1977). Through investigations of crop rotation systems, the knowledge of their effects on nematode population dynamics is advanced enough in the Maritime provinces to make recommendations. However, recommendations for a given crop may vary at a given location because of the difference in nematode species, cultural techniques, weather and soil conditions, and economic circumstances.

In general, the utilization of crop rotations or sequences for management of nematode pests in the Maritime provinces should be feasible. Pratylenchus penetrans is the only nematode species in the region that has caused yield losses to potato in the field (Kimpinski 1986), and to a lesser extent in tobacco and forage legumes (Arsenault et al. 1989; Thompson and Willis 1970). Meloidogyne hapla has caused some damage in carrots in New Brunswick and Prince Edward Island (J. Kimpinski, unpublished data), but this nematode species, together with $H$. trifolii, is more of a concern in the movement of seed potato tubers from this region to export markets in Latin American countries than they are to crop production. The removal of forage legumes in the rotation where potato or tobacco are the main crops, as has been the case for potato in New Brunswick, has suppressed populations of clover cyst and northern root-knot nematodes (Kimpinski and Smith 1988).

The situation is more difficult for $P$. penetrans, since this species is found to a greater or lesser degree in all the common agricultural crops of the Maritime provinces. However, the cultivation of more tolerant main crop cultivars and the use of non-hosts or poor hosts in the rotation can reduce the impact of root lesion and other plant parasitic nematodes. Tuber yields of the potato cultivars 'Russet Burbank', 'Shepody', and
'Kennebec' are not reduced by root lesion nematodes to the same degree as the cultivar 'Superior' (Kimpinski 1982, 1986). Annual ryegrass can replace red clover in the rotation with potato since annual ryegrass is not as good a host for root lesion nematodes as red clover (Kimpinski et al. 1984, 1988). In addition, annual ryegrass is not a host for northern root-knot nematodes and clover cyst nematodes (Taylor and Sasser 1978; Williams 1978).

\section{Chemical control}

Nematicides are probably the most efficient way to lower plant parasitic nematodes densities. The use of chemicals is economical when other methods of control do not suppress numbers of nematodes sufficiently to enable a grower to plant the major cash crop more often in the rotation (Hague and Gowen 1987). A major advantage of nematicides is that nematode population densities are reduced quickly, and crops can usually be planted immediately with nonfumigant nematicides, or a few weeks after treatment with fumigant nematicides. Other benefits are that certain chemicals, especially fumigants, control pests such as bacteria, fungi, insects, and weeds.

In the Maritime provinces, nematode damage in annual crops can be avoided by regular use of nematicides. However, because of the cost, chemical control is usually restricted to high-value or major crops such as tobacco and potato. Fumigant nematicides such as Telone-II (1,3-dichloropropene) are used in tobacco production, and the non-volatile carbamate nematicide, aldicarb (2-methyl-2-(methylthio)propionaldehyde 0 -methylcarbamoyloxime) has been used for insect control in potato, but it is also an excellent nematicide. Nematicides have been used on potato in the Maritime region primarily to control insects and nematodes and to increase potato tuber yields. However, certain countries such as Cuba or Mexico require that seed potatoes be free of some nematode species, such as clover cyst or northern root-knot nematodes. Nematicides are used to insure the absence of these species when potatoes are being grown for the export market.

The application of nematicides to agricultural crops in the Maritime provinces has 
resulted in yield increases when root lesion nematode populations were large. For example, chemical control of nematodes in experimental plots on Prince Edward Island has led to yield increases of $20 \%$ to $100 \%$ in forage legumes such as alfalfa, birdsfoot trefoil, and red clover (Thompson and Willis 1970, 1975), and of approximately $25 \%$ in strawberry (Kimpinski 1985). Similar studies in commercial potato fields, as well as in experimental plots, have resulted in $10 \%$ to $40 \%$ tuber yield increases (Kimpinski 1982, 1986). In tobacco, fumigant treatments have not led to consistent yield increases, but observations in commercial fields have indicated that quality and uniformity of the crop were improved (Kimpinski and Arsenault 1983; Kimpinski et al. 1976).

The improvement in crop yield and quality from nematicide treatments has usually been coincident with reductions in nematode populations. Nematicide trials with aldicarb and oxamyl ( $N, N$-dimethyl-2-methylcarbamoyloxyimino-2-(methylthio)acetamide), on Prince Edward Island, have often reduced nematode populations at the end of the growing season by as much as $90 \%$ when compared to untreated plots (Kimpinski 1979; Kimpinski et al. 1976; Willis and Thompson 1973). However, Morgan (1964), working with several fumigant nematicides in strawberry production in New Brunswick, found that populations of $P$. penetrans were greatly reduced a few days after treatment, but after 20 weeks nematode populations in some treated plots were not significantly different from levels in untreated check plots. More recently, in experimental potato plots on Prince Edward Island, carbamate pesticides such as aldicarb and oxamyl did not depress root lesion nematode to the same extent as in previous trials (Kimpinski 1986). It was suggested that specifically adapted microorganisms could degrade carbamates if these compounds were used for extended periods in acid mineral soils (Read 1983).

The major disadvantage of chemical control of nematodes is the possibility that residues of fumigants and nematicides may cause environmental damage. Residues of these chemicals occasionally have been detected in Canada and the United States in ground water, soil and plant products. For example, problems with groundwater contamination have occurred in several locations in North America, the most serious being on Long Island, New York, where frequent applications of aldicarb (3 to $5 \mathrm{~kg}$ a.i./ha) were used to control insects and nematodes (Marshall 1985). Aldicarb and its metabolites have also been found in groundwater at a few locations in Eastern Canada (Anonymous 1987). The use of aldicarb is now restricted in most parts of North America and is not available on Long Island. In the case of fumigants, trace amounts of bromine and chlorine residues have been detected in various crops in North America (Good 1972), including tobacco in Ontario (Elliot et al. 1972; Marks and Elliot 1975).

A second important disadvantage of nematicides is the price of the compounds. Nematicides have not been used in the Maritime provinces as much as in other parts of North America because of cost effectiveness. Chemical control of nematodes, especially with fumigants, is often more expensive than insect and weed control.

\section{Quarantine and sanitation}

In crop protection, quarantine refers to regulatory actions that prevent or retard the introduction, establishment, and spread of dangerous pests (Maas 1987). The principle which states that control is best achieved by excluding a pest for as long as practicable remains a sensible approach. The prevailing view is that the costs incurred in enforcing these regulations to prevent an introduction and infestation by a pest of an important crop are recouped many times.

Although nematodes can be moved by wind and water, man is often the main disseminator of important plant parasitic nematodes, usually through the transport of numerous types of plant material (Maas 1987). If entry and establishment do occur, the next step is to detect the pest before it spreads over a wide area. The third step is to either eradicate or contain the pest in a relatively small agricultural area. For example, in Eastern Canada, the golden nematode is confined to a relatively small area of Newfoundland. The spread of this serious pest of potato from infested to uninfested areas in Newfoundland, and to other parts 
of North America, is prevented by limiting or restricting movement of soil, machinery and vehicles containing soil, and various plant materials. As a sanitary measure, all vehicles are washed before they board the ferries to the mainland.

Effective and enforceable quarantine programs are based on the principle that biological and ecological information, coupled with knowledge of means of transport, is the key to a successful exclusionary program (Thomason and Caswell 1987). Baker and Bailey (1979), however, pointed out that a comprehensive knowledge of ecological requirements is lacking for most plant parasites. Assessments of the potential of individual species can therefore be based only on two factors: (i) the presence in the new area of host plants of the species, and (ii) the occurrence of the pest in areas of the world possessing a climate similar to that in the new area (Baker 1981). Therefore, the Columbia root-knot nematode (Meloidogyne chitwoodi Golden et al.), the soybean cyst nematode (Heterodera glycines Ichinohe), and the two species of potato cyst nematodes would fall under Baker's (1981) category of high-risk outdoor pests, capable of surviving and reproducing in many areas where host plants are widely grown in the Maritime region. To date, none of these species have been detected in New Brunswick, Nova Scotia, or Prince Edward Island.

\section{Cultural practices}

Turning of soil and fallowing can reduce the size of nematode populations, but this method of nematode control has received little attention because of its unfavorable effect on organic matter, soil structure, and soil erosion. In addition, the labor needed deters many growers from unproductive cultivation on large areas of land. The best control is obtained when fallow is maintained during hot dry weather (Johnson and Campbell 1980). Soil cultivation exposes nematodes to desiccation and prevents development of weed hosts. However, in the Maritime provinces where rainfall is usually plentiful during the growing season, fallowing is not very effective in controlling plant parasitic nematodes. For example, on Prince Edward Island, Willis and Thompson (1979) found that nematicides gave better nematode control than fallowing. They compared the effects of a non-fumigant nematicide (fenamiphos), a fumigant (methyl bromide), and fallowing on the numbers of $P$. penetrans and on forage yields of alfalfa over several growing seasons. Fallowing reduced numbers of nematodes least, while methyl bromide reduced numbers to below detectable levels. Initial control of nematodes by fenamiphos was comparable to that from fallowing, but the populations in the next year were not as high as in the fallow treatment, presumably because of the residual nature of fenamiphos. Foliage yields were highest in the methyl-bromide treated plots, followed in order by fenamiphos and fallowing.

There is increasing interest in minimum tillage practices to preserve soil structure, reduce soil erosion, save labour, and reduce production costs. Research in southern Australia (Rovira 1982) has shown that wheat sown by direct drilling is less severely damaged by the cereal cyst nematode (Heterodera avenae Wollenweber) than is wheat sown in soil tilled in the conventional manner. The beneficial effects of reduced cultivation were thought to be due to less mixing of cysts and larvae of $H$. avenae in the soil. Kimpinski and Kunelius (1988) also observed that populations of another cyst nematode, $H$. trifolii, were lower in minimum tillage plots than in conventional tillage plots of red clover on Prince Edward Island.

It is generally accepted that the incorporation of various amendments into soil can influence nematode populations (Brown 1987). An increase in soil $\mathrm{pH}$ from approximately 5.0 to about 6.5 under greenhouse conditions led to an increase in the size of populations of $P$. penetrans in alfalfa, but the reverse was the case for a similar $\mathrm{pH}$ range in timothy (Kimpinski and Willis 1981; Willis 1972). This indicated that the optimum $\mathrm{pH}$ range for $P$. penetrans varies with the species of host plant. In alfalfa, $P$. penetrans reproduced more rapidly at a higher $\mathrm{pH}$ range than the less pathogenic $P$. crenatus.

Morgan and Collins (1964) applied organic amendments to strawberry fields in New Brunswick and found that composted 
timothy hay suppressed populations of $P$. penetrans more than did cow manure. However, the reductions were, at best, only about $32 \%$ when compared to nematode populations in actively growing timothy sod. These types of studies have not been carried out elsewhere in the Maritime provinces.

\section{Nematode advisory services}

These services usually are based on analysis of soil samples prior to seeding the main crop, and are diagnostic, regulatory, and predictive in nature. In the Maritime provinces, several hundred samples are analyzed for nematodes each year.

There is a direct relationship between population densities of plant parasitic nematodes and damage to host plants (Barker and Olthof 1976). However, a major problem of nematode advisory services is that plant damage from nematodes can be influenced by the weather, other pathogens, soil type, and crop management (Barker and Imbriani 1984). Another difficulty is that determination of nematode counts is imprecise. Based on calculations by Proctor and Marks (1974) in Ontario, the sampling schemes used for diagnostic samples in the Maritime provinces provide estimates only to within about $50 \%$ of the true population mean. More data at various locations with different soil and weather conditions, with other potato cultivars or different crop rotations, with more precise knowledge of winter survival of nematodes, and improved sampling schemes, should provide better estimates of nematode density.

Another difficulty for an advisory service in the Maritimes is the lack of time in the spring to return information to growers before planting. In this region we know that 2000 to $3000 P$. penetrans per $\mathrm{kg}$ of soil at planting will reduce tuber yields of potato cv. Superior (Kimpinski and McRae 1988) and about $50 \%$ of root lesion nematodes survive the winter (Kimpinski and Dunn 1985). Based on these figures, it should be possible to predict whether root lesion nematodes will cause economic damage or not to the ensuing potato crop. As more information is obtained from diagnostic samples, from concurrent experimental studies on winter survival of nematodes, and on determination of threshold levels at which nematodes cause economic damage, it should be possible to provide growers with a reliable advisory service.

\section{Outlook}

The management and control of plant parasitic nematode populations in agricultural crops in the Maritime provinces will require an integrated approach. Although nematicides will still be used, other control tactics, which include crop rotations, cultural practices, sanitation and quarantine, are expected to become more popular. Biological control, in which natural enemies attack plant parasitic nematodes, may play an important role in future, though any practical application of this approach in the Maritime provinces will require considerable research.

We thank B. E. Hopper, Plant Protection Division, Food Production and Inspection Branch, Agriculture Canada, Ottawa, and C. B. Willis, Research Branch, Agriculture Canada, Ottawa, for reviewing the manuscript and for helpful suggestions.

Anonymous. 1987. Concerns about aldicarb. Pesticide Information, Vol. 9(1). Scientific Information Retrieval Section, Research Branch, Agriculture Canada, Ottawa. 16 pp.

Arsenault, W.J., J. Kimpinski, and J.A. MacLeod. 1989. Root lesion nematodes and flue-cured tobacco yields in a rye-tobacco or soybean-tobacco crop sequence. Tob. Sci. 33: 72-73.

Baker, A.D. 1946. The potato-rot nematode, Ditylenchus destructor Thorne, 1945, attacking potatoes in Prince Edward Island. Sci. Agric. 26: 138-139.

Baker, C.R.B. 1981. Assessing risks from exotic pests. Eur. Mediterr. Plant Prot. Organ. Bull. 11: 145-150.

Baker, C.R.B., and A.G. Bailey. 19'79. Assessing the threat to British crops from alien diseases and pests. Pages 43-54 in D.L. Ebbels and J.E. King (eds.), Plant health: the scientific basis for administrative control of plant diseases and pests. Blackwell, Oxford.

Barker, K.R., and J.L. Imbriani. 19:84. Nematode advisory programs - status and prospects. Plant Dis. 68: 735-741.

Barker, K.R., and G.B. Lucas. 1984. Nematode parasites of tobacco. Pages 213-242 in W.R. Nickle (ed.), Plant and insect nematodes. Dekker, New York.

Barker, K.R., and T.H.A. Olthof. 1976. Relationships between nematode population densities and crop responses. Annu. Rev. Phytopathol. 14: 327-353.

Brodie, B.B. 1984. Nematode parasites of potato. Pages 167-212 in W.R. Nickle (ed.), Plant and insect nematodes. Dekker, New York. 
Brown, R.H. 1987. Control strategies in low-value crops. Pages 351-387 in R.H. Brown and B.R. Kerry (eds.), Principles and practice of nematode control in crops. Academic Press, Australia.

Elliot, J.M., C.F. Marks, and C.M. Tu. 1972. Effects of nematicides on Pratylenchus penetrans, soil microflora, and flue-cured tobacco. Can. J. Plant Sci. 52: 1-11.

Good, J.M. 1972. Bionomics and integrated control of plant parasitic nematodes. J. Environ. Qual. 1: 382-386.

Hague, N.G.M., and S.R. Gowen. 1987. Chemical control of nematodes. Pages 131-178 in R.H. Brown and B.R. Kerry (eds.), Principles and practice of nematode control in crops. Academic Press, Australia.

Johnson, A.W., and G.M. Campbell. 1980. Managing nematode population densities on tomato transplants using crop rotation and a nematicide. J. Nematol. 12: 6-19.

Kimpinski, J. 1975. Nematodes associated with vegetables in Prince Edward Island, Canada. Plant Dis. Rep. 59: 37-39.

Kimpinski, J. 1979. Root lesion nematodes in potatoes. Am. Potato J. 56: 79-86.

Kimpinski, J. 1982. The effect of nematicides on Pratylenchus penetrans and potato yields. Am. Potato J. 59: 327-335.

Kimpinski, J. 1984. Plant parasitic nematodes in soybeans. Forage Notes 28: 21-23.

Kimpinski, J. 1985. Nematodes in strawberries on Prince Edward Island, Canada. Plant Dis. 69: 105-107.

Kimpinski, J. 1986. Effects of aldicarb and oxamyl on Pratylenchus penetrans and potato yields. Can. J. Plant Pathol. 8: 189-192.

Kimpinski, J. 1987. Nematodes associated with potato in Prince Edward Island and New Brunswick. Ann. Appl. Nematol. 1: 17-19.

Kimpinski, J., and W.J. Arsenault. 1983. Nematodes in tobacco in Prince Edward Island. The Lighter 52(2): 23-27.

Kimpinski, J., and R.A. Dunn. 1985. Effect of low temperatures in the field and laboratory on survival of Pratylenchus penetrans. Plant Dis. 69: 526-527.

Kimpinski, J., and H.T. Kunelius. 1988. Effects of conventional and minimum tillage on nematode populations in red clover and timothy. Forage Notes 32: 14-16.

Kimpinski, J., and J.A. MacLeod. 1988. Plant parasitic nematodes in lupins and soybeans. Forage Notes 33: 25-27.

Kimpinski, J., and K.B. McRae. 1988. Relationship of yield and Pratylenchus spp. population densities in Superior and Russet Burbank potato. Ann. Appl. Nematol. 2: 34-37.

Kimpinski, J., and H.W. Platt. 1983. Washing of potatoes to remove nematodes and to observe effect on storage rot diseases. Can. Plant Dis. Surv. 63: 45-46.

Kimpinski, J., and E.M. Smith. 1988. Nematodes in potato soils in New Brunswick. Can. Plant Dis. Surv. 68: 147-148.

Kimpinski, J., and C.B. Willis. 1980. Influence of crops in the field on numbers of root lesion and stunt nematodes. Can. J. Plant Pathol. 2: 33-36.
Kimpinski, J., and C.B. Willis. 1981. Influence of soil temperature and $\mathrm{pH}$ on Pratylenchus penetrans and $P$. crenatus in alfalfa and timothy. J. Nematol. 13: 333-338.

Kimpinski, J., K.E. LeLacheur, C.F. Marks, L.S. Thompson, and C.B. Willis. 1976. Nematodes in tobacco in the Maritime Provinces of Canada. Can. J. Plant Sci. 56: 357-364.

Kimpinski, J., L.S. Thompson, R.P. White, and C.B. Willis. 1977. Nematodes in field corn in Prince Edward Island. Can. J. Plant Sci. 57: 323-330.

Kimpinski, J., H.T. Kunelius, and C.B. Willis. 1984. Plant parasitic nematodes in temperate forage grass and legume species in Prince Edward Island. Can. J. Plant Pathol. 6: 160-164.

Kimpinski, J., H.W. Johnston, and R.A. Martin. 1987. Influence of aldicarb on root lesion nematodes, leaf disease and root rot in wheat and barley. Plant Pathol. 36: 333-338.

Kimpinski, J., H.T. Kunelius, and B.N. Craig. 1988. Occurrence of plant-parasitic nematodes in forage legumes and grasses. Forage Notes 32: 30-32.

Kimpinski, J., R.V. Anderson, H.W. Johnston, and R.A. Martin. 1989. Nematodes and fungal diseases in barley and wheat on Prince Edward Island. Crop Prot. 8: 412-416.

Kunelius, H.T. 1980. Effects of nitrogen rates and harvest schedules on yield and quality of Westerwolds ryegrass grown as a summer annual. Can. J. Plant Sci. 60: 519-524.

Kunelius, H.T., and F.W. Calder. 1978. Effects of rates of $\mathrm{N}$ and regrowth intervals on yields and quality of Italian ryegrass grown as a summer annual. Can. J. Plant Sci. 58: 691-697.

Maas, P.W. Th. 1987. Physical methods and quarantine. Pages 265-291 in R.H. Brown and B.R. Kerry (eds.), Principles and practice of nematode control in crops. Academic Press, Australia.

MacDonald, D.H., and W.F. Mai. 1963. Suitability of various cover crops as hosts for the lesion nematode, Pratylenchus penetrans. Phytopathology 53 : 730-731

Marks, C.F., and J.M. Elliot. 1975. Control of the root-lesion nematode (Pratylenchus penetrans) in flue-cured tobacco in Ontario. Can. J. Plant Sci. 55: 309-314.

Marshall, E. 1985. The rise and decline of Temik. Science (Wash. D.C.) 229: 1369-1371.

Morgan, G.T. 1964. Effects of spring preplanting fumigation in strawberry soil in New Brunswick. Can. J. Plant Sci. 44: 170-174.

Morgan, G.T., and W.B. Collins. 1964. The effect of organic treatments and crop rotation on soil populations of Pratylenchus penetrans in strawberry culture. Can. J. Plant Sci. 44: 272-275.

Morris, R.F. 1971. Distribution and biology of the golden nematode, Heterodera rostochiensis in Newfoundland. Nematologica 17: 370-376.

Nusbaum, C.J., and H. Ferris. 1973. The role of cropping systems in nematode population management. Annu. Rev. Phytopathol. 11: 423-440.

Olthof, T.H.A., B.D. McGarvey, and M. Chiba. 1985. Oxamyl in the control of Pratylenchus penetrans on potatoes. Can. J. Plant Pathol. 7: $155-160$ 
Proctor, J.R., and C.F. Marks. 1974. The determination of normalizing transformations for nematode count data from soil samples and of efficient sampling schemes. Nematologica 20: 395-406.

Read, D.C. 1983. Enhanced microbial degradation of carbofuran and fensulfothion after repeated applications to acid mineral soil. Agric. Ecosyst. Environ. 10: 37-46.

Rovira, A.D. 1982. Management strategies for controlling cereal cyst nematode. CSIRO Division of Soils, Adelaide. 9 pp.

Sasser, J.N., and C.C. Carter. 1985. Overview of the international Meloidogyne project 1975-1984. Pages 19-24 in J.N. Sasser and C.C. Carter (eds.), An advanced treatise on Meloidogyne, Vol. 1, biology and control. North Carolina State Univ., Raleigh, N.C.

Taylor, A.L., and J.N. Sasser. 1978. Biology, identification, and control of root-knot nematodes (Meloidogyne species). Coop. Publ. Dep. Plant Pathol., North Carolina State Univ., and U.S. Agency Int. Dev., Raleigh, N.C. 111 pp.

Thomason, I.J., and E.P. Caswell. 1987. Principles of nematode control. Pages 87-130 in R.H. Brown and B.R. Kerry (eds.), Principles and practice of nematode control in crops. Academic Press, Australia.

Thompson, L.S., and C.B. Willis. 1967. Distribution and abundance of Sitona hispidula (F.) and the effect of insect injury on root decay of red clover in the Maritime Provinces. Can. J. Plant Sci. 47: 435-440.

Thompson, L.S., and C.B. Willis. 1970. Effect of nematicides on root lesion nematodes and forage legume yields. Can. J. Plant Sci. 50: 577-581.

Thompson, L.S., and C.B. Willis. 1975. Influence of fensulfothion and fenamiphos on root lesion nematode numbers and yield of forage legumes. Can. J. Plant Sci. 55: 727-735.

Waseem, M., and D.L. Craig. 1962. A survey of plant-parasitic nematodes in strawberry fields of Nova Scotia. Plant Dis. Rep. 46: 586-590.
Williams, T.D. 1978. Cyst nematodes: biology of Heterodera and Globodera. Pages 156-171 in J.F. Southey (ed.), Plant nematology. Ministry of Agriculture, Fisheries, and Food, H.M.S.O., London.

Willis, C.B. 1972. Effects of soil pH on reproduction of Pratylenchus penetrans and forage yield of alfalfa. J. Nematol. 4: 291-295.

Willis, C.B. 1976. Susceptibility of sainfoin cultivars to the northern root knot nematode. Can. J. Plant Sci. 56: 981-983.

Willis, C.B. 1981. Reaction of five forage legumes to Meloidogyne hapla. Plant Dis. 65: 149-150.

Willis, C.B., and L.S. Thompson. 1967. Root-lesion nematodes associated with forage legumes in the Maritime Provinces. Can. Plant Dis. Surv. 47: 87-88.

Willis, C.B., and L.S. Thompson. 1969a. Effect of the root-lesion nematode on yield of four forage legumes under greenhouse conditions. Can. J. Plant Sci. 49: 505-509.

Willis, C.B., and L.S. Thompson. 1969b. The influence of soil moisture and cutting management on Pratylenchus penetrans reproduction in birdsfoot trefoil and the relationship of inoculum levels to yields. Phytopathology 59: 1872-1875.

Willis, C.B., and L.S. Thompson. 1973. Control of Pratylenchus penetrans in birdsfoot trefoil with oxamyl. Plant Dis. Rep. 57: 237-240.

Willis, C.B., and L.S. Thompson. 1979. Effects of phenamiphos, methyl bromide, and fallowing on Pratylenchus penetrans, yield of Medicago sativa, and Fusarium infections. J. Nematol. 11:265-269.

Willis, C.B., A.L. Henderson, D.J. Hough, and J.D. Secord. 1971. Nematodes associated with forage legume crops in Nova Scotia. Can. Plant Dis. Surv. 51: 93-95.

Willis, C.B., J.L. Townshend, R.V. Anderson, J. Kimpinski, R.H. Mulvey, J.W. Potter, J. Santerre, and L.Y. Wu. 1976. Species of plant-parasitic nematodes associated with forage crops in eastern Canada. Plant Dis. Rep. 60: 207-210. 